\title{
The implementation of online learning in efl classroom: its opportunities and drawbacks perceived by teachers and students
}

\author{
Perta Rasia Dewi ${ }^{1}$ \\ ${ }^{1}$ Universitas PGRI Palembang, Indonesia
}

\begin{tabular}{l} 
Article Info \\
\hline Article history: \\
Received Jul $20^{\text {th }}, 2021$ \\
Revised Aug $12^{\text {th }}, 2021$ \\
Accepted Aug $30^{\text {th }}, 2021$ \\
\hline
\end{tabular}

\section{Keyword:}

Pandemic covid-19

Online learning

Opportunities

Drawbacks

\begin{abstract}
The spread of the corona virus in various parts of the world has led to policy changes in various sectors of life, including the education sector. In order to inhibit the spread of the corona virus and in an effort to break the chain of spread of viruses that have not yet found a vaccine, governments in various countries affected by the covid-19 virus have made policies to carry out online learning. Likewise in Indonesia, the Indonesian government has officially enforced rules for implementing online learning since March 16, 2020. In practice, however, there are various drawbacks perceived by teachers and students in addition to online learning opportunities. Therefore, this study has aimed to determine the opportunities and drawbacks perceived by teachers and students in the implementation of online learning in East Baturaja district during the covid-19 pandemic. The research was conducted in SMPN 32 OKU, East Baturaja district, OKU Regency. The participants were 7th grade students and English teachers who were selected by purposive sampling method. Interviews according to health protocols with 4 questions and observations were made in data collection. The result show that teachers and students perceived that online learning offered flexibility, offered latest news, offered rich and unrestricted tools, facilitated reading, and helped to become more active for less active students, and was fast and easier. However, considering the advantages for learners as online learning is integrated into teaching and learning, there are certain drawbacks that demand immediate attention.
\end{abstract}

(C) 2021 The Authors. Published by IICET.

This is an open access article under the CC BY-NC-SA license (https://creativecommons.org/licenses/by-nc-sa/4.0

\section{Corresponding Author:}

Dewi, P, R.,

Universitas PGRI Palembang, Indonesia

Email: pertarasiadewi22@gmail.com

\section{Introduction}

In Indonesia, government policies in dealing with the corona virus also have an impact on the education system in Indonesia. Regarding the Prevention of Corona Virus Disease (COVID-19) in the Education Unit which stated that schools and colleges were closed.[1] This is done to break the chain of spreading COVID-19, instead learning activities are carried out online for all levels of education.[2] Indonesia is currently starting to start the beginning of a new normal. This needs to be continually supported and strengthened with various disaster mitigation education that has been carried out during the physical distancing period at th beginning of 2021.[3] Many families around the world felt severe short-term disruption. Distance learning is not only a massive shock to parents' productivity, but also to children's social life and learning. The process of teaching is moving online, on an untested and unprecedented scale. Student assessments are also moving online, with a lot of trial and error and uncertainty for everyone. Many assessments have simply been cancelled. 
This online learning makes teachers overwhelmed in creating a process of teaching and learning. Actually, due to technological advances some of modern schools have implemented online learning but the implementation is limited.[4] Other schools which lack of technological facilities still have problems in conducting distance learning. SMPN $32 \mathrm{OKU}$ is one school that implements this policy. Online learning is a method of information technology advancement that can be used as a learning tool [5]

Online learning is defined as a computer network that is interconnected with other computer networks around the his online learning application can facilitate training and learning activities as well as formal and informal teaching and learning processes, as well as facilitating activities and communities of electronic media users, such as the internet, intranet, CD-ROM, video, DVD, television, cellphone, PDA, and others.[6] In implementing online learning, teachers and students have their respective roles. In learning events, teachers have a role as facilitators and guides, while students have a role as knowledge builders, independent learners and problem solvers. [7] In addition, the term online learning includes various applications and processes such as computer-based learning, web-based learning, virtual classrooms, virtual Schoology, virtual Zoom, and other applications. (Da'wah et al., N.d.) This study intends to explore the opportunities and drawbacks faced by teachers and students in implementing in online learning.

\section{Method}

A sample was a small group that is observed. Purposive sampling implemented to select the participants [8]. "In purposive sampling, the researcher intentionally selects individuals and sites to learn or understand the phenomenon" [9]. Students who actively participate in the online learning activities were chosen. In this case, they who actively give responses, reply to the posts, give comments and feedbacks and also help the other friends. Since students who are active and contribute themselves in the discussion are considers having richer experience than the others. Thus, they will also provide more detail and insight into information and perception about the online learning implementation, as supported by Crasswell [10] that "the standard in choosing of participants and sites is whether they are "information rich" (p. 206). In this study the in-depth interviews were all recorded and conducted in Bahasa Indonesia with which the participants felt convenient. All names are pseudonyms.

In this study, the participants are English teachers who taugh in SMPN 32 OKU and students in the seventh grade. It will involve 2 English teachers and 6 students in seventh grade. Sample of the students will select from class A to class $\mathrm{H}$. In this case, students who actively participate in the online learning activities were chosen.

A qualitative research was used by the researcher to find the result of the study. Ary said in his book Introduction in Research in Education that qualitative research is carried out to explain the present state of the phenomenon that occurs at the time of the analysis. [11] in Research Approach in Education often mentioned that qualitative analysis requires the categorization and perception of data in the way it serves the overall portrait of the case in terms of popular topics.

In this study, researcher used Interview, observation, and documentation technique to answer the research question. The researcher interviewed two teachers and six students that chose by purposive sampling. The researcher did face to face in the interview in the school when interviewed the teachers but still followed government instructions for physical distancing and used mask and face shield. Meanwhile, government guidelines on physical distance during the COVID-19 outbreak were performed through telephone interviews to prevent physical meetings when she interviewed students. The interview conducted three times to see consistency in participants' response. Meanwhile, the in-depth interview conducted to two teachers and six students. The interview which consists of four questions aimed to gain in-depth explanation and description on the teachers' and students' perception of the opportunities and drawbacks of online learning.

In addition, the researcher utilized a system of triangulation that included depth interview, observation, and documentation. Triangulation has been used as a qualitative analysis tool for validation study by integrating knowledge from multiple sources. Triangulation has been used as a qualitative analysis tool for validation study by integrating knowledge from multiple sources.[12] In order to improve the validity of this study, the researcher used the triangulation process. Three separate techniques were used in the collection of data. These techniques were depth interview, observation, and documentation.

Moreover, the observation administered to figure out the implementation of online learning at SMP N 32 OKU. In the observation checklist there were five points of e-moderating stages to deal with the implementation of Sumsel Cerdas and Google Classroom as online learning platform in English learning activities in SMPN 32 OKU. Observation checklist for identifying the implementation of Sumsel Cerdas, 
Google Classroom and WhatsApps is design using "Yes" or "No" checklist based on the stages of implementing e-moderating. In did observation, field note was also needed to help the researcher avoiding the lack of information. The function of field note here for helping the researcher completed the observation checklist. This instrument used by the researcher to answer the first research question.

The used of documentation in this study to support the data and to improve the validity of this study. The document is considered notes that are written with the contents statements that are organized as data by someone or organization source of [13] ]in this study researcher. The documentation that the researcher used were lesson plan and screenshot of the Portal of Teachers and Students in Sumsel Cerdas, Google classroom and whatApps, what a researcher wants.

Qualitative analysis involves categorization and description of data in terms of common themes in the manner it serves the overall portrait of the case is used.[14] For the present study, themes for analysis are identified from re-reading of the interviews scripts. In general, data analyzed in terms of the three major themes which are the teachers' and students' perception on: first, the use of online learning toward the English learning activities; second, the opportunities of online learning implementation; and last was the drawback online learning implementation. Additionally, several efforts made to address validity and reliability issues in the qualitative data analysis. Possible factual errors in the interview data were checked by cross-checking. The transcription interviews are delivered for analysis to each participant.

The interview data will all transcribed and analyzed for repeating key features which will related to the opportunities and drawbacks of online learning platforms in the classroom. The reappearing of particular opinion can be assumed as the participants' concern towards the issue. The data from the observation and interview were used to provide description of teachers' and students' perception on the opportunities and drawbacks of online learning platforms such as Sumsel Cerdas, Google Classroom and Whatsapp and the benefits felt by teachers and students after using the learning platforms in English teaching and learning process

\section{Results and Discussions}

\section{The Implementation of Online Learning in EFL Classroom at SMPN 32 OKU}

The researcher collected the data regarding with the first research question of the study which is how the implementation of Online learning in English learning runs. The learning process during the use of Sumsel Cerdas, Google Classroom and WhatApps as online learning platform had been analyzed by the researcher based on what happened in the class.

In this study, there are 5 phases in the implementation of e moderation based on Gilly Salmon's theory, which is the subject of this study. When using online learning efficiently, the teacher needs to understand how those phases are applied. Therefore, this section clarified the manner in which the teacher applied Sumsel Cerdas, Google Classroom and WhatApps as an online learning platform for English learning. Based on the outcome of the observation, those activities were carried out by the teacher in the implementation of each emoderating process.

Based on the table which is about the result of classroom observation about the implementation of Sumsel Cerdas and Google Classroom as online learning platform in English learning activities, the researcher found out that the teacher implemented three from five stages in the implementation of e-moderating. In addition, the stage that the teacher has not implemented is online socialization and knowledge construction.

Table 1. The Result of Observation Checklist in Implementing Google Classroom

\begin{tabular}{lllll}
\hline So & $\begin{array}{l}\text { Stages in the implementation of } \\
\text { emoderating }\end{array}$ & Yes & No & Activities
\end{tabular}


Access and motivation

a. Access

b. Motivation

c. Arriving

2. Online Socialization

3. Information exchange

5. Development a. Through the WhatApps Group, teacher invite students to open Google Classroom application

b. The teacher gives the students an access code to join group in Google Classroom

c. The teacher makes sure that all students have joined in right group

a. The teacher asks student whom get trouble in open Google Classroom to ask by WhatApps

b. The teacher advises the student whom open other site during learning process

a. The teacher always give students time limit to do the tasks in Google Classroom

a. Through WAG, the teacher asks the students to learn learning materials in Google Classroom

b. The teacher asks students to watch video in Google Classroom or WAG

a. The teacher give explanation and example before asking the students to do assignment in Google Classroom

a. The teacher gives homework to the students in Google Classroom

\section{Teachers' and Students' Perception toward the Opportunities of Online Learning Implementation in} English Learning at SMPN 32 OKU

The researcher collected the data regarding with the second research question of the study which is the opportunities in implementation of online learning in English learning perceived by teachers' and students'. To know the teachers' and students' perception, the researcher gained the data from doing interview to the teachers and students who have chosen by use purposive sampling because it was hard to do interview one by one to all English Teachers and all 7th grade students. Interviews were conducted with two English teachers who teach in grade 7 of SMPN 32 OKU and six grade 7 students of SMPN 32 OKU who are active in online learning activities. There are 4 similar questions that were asked to each selected participant, namely:

Do you carry out online learning activities?

How do you carry out online learning?

What opportunities do you feel in implementing online learning?

What drawbacks do you find in implementing online learning?

The data shows that online learning "given flexibility," "given updated information," "given rich, unlimited resources," "encouraged students to read," "helped less active students become more active," and "was quicker and simpler." Online learning provides flexibility. From the interviews, flexibility became the key opportunity provided by online learning. Flexibility refers to the ease of access that students can access from anywhere and 
at any time. Mrs. Cinta and Mrs. Puji said that online learning offered flexibility in terms of time and place. In the interview they stated:

"We can teach, for teachers ya, anywhere, while cooking, while watching children play, we can send assignments, answer student questions and others (Mrs. Cinta).

As stated by the teachers, the students interviewed also stated that online learning offers flexibility. Meli, Rosi, Chelsea, Anton, Aris, and Frisda said that online learning provides flexibility in term of time and place. In interview they stated:

"I think online learning is good because we can learn from home, we don't have to go to school and we can study anytime (Meli). Learning online is fun because we don't have always go to school (Anton) I think learning online is good because we can learn from home and don't have to go to school so we are not afraid of getting corona. We can also study at any time (Chelsea)."

The participants made some strong points regarding the flexibility in online learning. First, online learning was not limited to space and time. Second, by having online learning, students could learn from any places, not only from classroom. The last, to be able to access online learning, a reliable internet connection was imperative. That online learning provides flexibility in learning is supported by [15] who argued that online learning brings the flexibility and convenience because online learning allows students to access the lesson anytime and anywhere, and students can complete the lesson units at their own pace. Online learning provides updated information.[16] The second opportunity of online learning perceived by the participants was that it provided updated material and information. Both teachers, Mrs. Cinta [16] shared their experience that they could share updated information or material to their students. And also the students; Frisda, Chelsea, and Meli shared their experience that they could immediately get updated information or material from the teacher.

"If there is an information that should shared to the student, I can share it immediately (Mrs. Puji). When we want to give a new imformation to students we can send it immediately via WhatsApps (Mrs. Cinta)"

"Updated information as internet always provides updated information, even in a second, it has new information (Meli). We become more updated. So, if the teacher gives information or assignment, we can directly know it, as there is a notification. So, we do not need to meet the teachers and do not need to wait until the Due-day we can know what the news or the assignment is (Rosi). The opportunity of e-learning is on the updated material (Aris).

Online learning provides rich, unlimited resources. The next opportunity of online learning the students perceived was that online learning provided rich and unlimited resources, as Meli and Rosi stated, such as references for assignment, learning materials, and examples or task for language skills practices. [16] Hwee revealed that using online learning, students became freer as it was not face to face. In online learning, he added, they could freely explore resources, and found knowledge. Online learning provides free and easy access for students to find out the resources which are helpful for them in completing an assignment. A similar comment was made by Frisda, who stated that online learning also provided them with rich, unlimited resources.

\section{Teachers' and Students' Perception On The Drawback Of Online Learning Implementation In Language Learning}

There are also drawbacks to remember, as in any approach to learning. The possible drawbacks of innovation primarily used during language learning should not be dismissed. Thus, the other purpose of this study regarding the use of online learning was investigating the drawbacks or complexity that online learning had created perceived by teachers and students. During the interviews, the participants shared their stories with regard to the drawbacks of online learning implementation. They stated that online learning "decreased direct interactions" and "decreased verbal language" in terms of social interaction. In addition, "it was costly". Other drawback they remarked is in terms of technical problems, such as online learning required "adequate technological skills" and "good internet access or connection". Last but not least, online learning "did not allow feedback from real or direct teachers" and "increased plagiarism and cheating possibilities."

Online learning decreases social interaction. All participants, teachers and students remarked that online learning decreased social interaction. They argued that compared to the classroom activity, the interaction atmosphere in online learning was limited as the activities were conducted virtually. [12] said that she found difficulty in to know the character of students. Not different with Mrs. Puji, Mrs Cinta also said that she found difficulty to discuss with her students or to motivate her students to discuss each other. Meli explained that the drawback of online learning was that it did not allow face-to-face interaction atmosphere among students and 
teachers, and student and student. She explained further that on one side, online learning was good, but on the other side, teachers cannot disregard face to face learning. The same point was experienced by Aris who maintained, "online learning decreased interaction among students". He considered that online learning generated a passive interaction as its interaction was limited to a written language. In addition to Meli and Aris, Rosi explicitly stated, "also, in my opinion, online learning reduces the frequency of meeting up with friends and with the teacher, so, it reduces the social interaction" [13]. The last participant who agreed that online learning decreased face-to-face interaction was Frisda. She found out that online learning hindered her from direct social interaction. She then argued that because it was an online learning, she was unable to communicate face-to-face so that facial expression could not be seen. The facial expression belongs to the body language, which in communication is essential. It helps students understand utterances better.

\section{Conclusions}

Evidence from this study showed that participants had similar views of online learning implementation. In general, teachers and students perceived that online learning offered flexibility, offered latest news, offered rich and unrestricted tools, facilitated reading, and helped to become more active for less active students, and was fast and easier. However, considering the advantages for learners as online learning is integrated into teaching and learning, there are certain drawbacks that demand immediate attention. Drawbacks such as declining social contact and oral communication, expensive, lack of technical skills, lack of digital tools, slow access or connection to the internet, lack of real or direct input from students, and growing possibility of plagiarism and cheating served as obstacles to the full potential of online learning. These findings are consistent with the outcomes of comparable studies performed at major institutions and demonstrate the value of online learning.

This study proposes some strong notes for online learning users, including teachers and school administrators, with regard to the introduction of online learning. Firstly, some students might not be familiar with the use of online learning since they come from various social background and technology literacy levels. Therefore, teachers are responsible to give demonstration or guideline to students dealing with how to operate this online learning. Secondly, using various types of online learning, e.g. using video call or zoom, is strongly recommended. By doing so, students can enhance both oral communication in face-to-face learning and nonverbal communication. Thirdly, teachers should discuss the materials which they discussed in class at online learning session more intensively to get better understanding. Then, if the content was misunderstood, the teacher may also provide explanation or correction. In addition, teachers are encouraged to use different content, activities, and sites to design their online learning to reduce monotonous activities and provide meaningful learning experiences. Lastly, teachers need to check and provide constructive feedback on students' works in order to avoid cheating and plagiarism. In order to enhance the efficacy of online learning environment, teachers and students must be provided with ample supports by school administrators.

\section{References}

Ilyasa, F., Rahmayanti, H., Muzani, M., Ichsan, I. Z., \& Suhono, S. (2020). Environmental education for prevent disaster: a survey of students knowledge in beginning new normal of COVID-19. International Journal on Advanced Science, Education, and Religion, 3(2), 1-8.

Rahimah, R., Juriah, N., Karimah, N., Hilmatunnisa, H., \& Sandra, T. (2020). The Problems and Solutions for Learning Activities during Covid-19 Pandemic Disruption in Hidayatul Insan Pondok School. Bulletin of Community Engagement, 1(1), 13-20.

Khadijah, I. (2021). The Competency of Science Teachers in Implementation of Online Learning In Covid-19 Pandemic Period at SMPN 2 Kramatwatu Serang. Bulletin of Science Education, 1(1), 60-67.

Wawan, W., Marsigit, M., Ningsih, E. F., Widyawati, S., Kusumaningtyas, W., Mahmudi, M., ... \& Setiawan, A. (2018). Technology-Integrated Collaborative Learning: Convenient Al-ternative in Developing the Problem Solving Capability and Positive Attitude. International Journal of Engineering \& Technology, 7(3.2), 737-740.

Hartanto, W. (2016). Penggunaan E-Learning sebagai Media Pembelajaran. Jurnal Pendidikan Ekonomi, $10(1), 1-18$.

Al-kathiri, F. (2015). Beyond the classroom walls : Edmodo in Saudi Secondary School EFL instruction, attitudes and challenges. English Language Teaching, 8(1), 189-204. https://doi.org/10.5539/elt.v8n1p189

Arikunto, S.(2006). Prosedur Penelitian Suatu Pendekatan Praktik. Jakarta Rineka Cipta.

Al-said, K. M. (2015). Students ' Perceptions of Edmodo and mobile learning and their real barriers towards them. TOJET: The Turkish Online Journal of Educational Technology, 14(2), 167-180. 
Creswell, J. W. (2009). Research design: Qualitative, quantitative, and mixed methods approaches. Thousand Oaks, California: SAGE Publications, Inc.

Archambault, L., Wetzel, K., Foulger, T. S., \& Williams, M. K. (2016).Professional development 2.0.Journal of Digital Learning in Teacher Education, 2974(April), $2153-$ 2974.https://doi.org/10.1080/21532974.2010.10 784651

Balasubramanian, K., Jaykumar, V., \&Fukey, L. N. (2014).A Study on "Student preference towards the use of Edmodo as a learningplatform to create responsible learning environment."Procedia - Social and Behavioral Sciences, 144, 416-422. https://doi.org/10.1016/j.sbspro.2014.07.3 11

Chapelle, C. (2003). English language learning and technology: Lectures on applied linguistic in the age of information and communication technology (Vol. 7). Amsterdam, Philadephia: John Benjamins Publishing.

Ekmekçi, E. (2016). Integrating Edmodo into foreign language classes as an assessment tool.Participatory Educational Research, 1, 1- 11.https://doi.org/http://dx.doi.org/10.172 75/per.16.spi.1.1

Framework for 21st Century Learning. (2009). Retrieved from http://www.p21.org/ourwork/p21-framework

Enriquez, M. (2014) Students' perception on the effectiveness of the use of Edmodo as a supplementary tool for learning. Paper Presented at the DLSU Research Congress 2014: Philippines. De La Salle University, Manila, Philippines. March 6-8, 2014. retrieved from http://www.dlsu.edu.ph/conferences/dls u_re search.../_pdf/LLI-II-010.pdf

Hwee, J., Koh, L., \& Chai, C. S. (2016). Teacher professional development for TPACK21CL : Effects on teacher ICT integration and student outcomes. Journal of Educational Computing Research, 1-25. https://doi.org/10.1177/073563311665684 8 